\title{
DESAIN PRODUK MAKANAN LOKAL BERBASIS INDUSTRI KECIL MENENGAH
}

\author{
Ali Alamsyah Kusumadianata ${ }^{1)}$ \& Maria Fitriah $^{2)}$ \\ ${ }^{1)}$ Dosen Prodi Ilmu Komunikasi, Universitas Djuanda,Bogor \\ ${ }^{2)}$ Dosen Prodi Ilmu Komunikasi, Universitas Djuanda, Bogor \\ Email:alialamsyahkusumadinata@gmail.com
}

\begin{abstract}
Increasing the number of local food businesses in the form of products that are worth selling the industry is increasing in quantity and quality. Bogor is one of the tourist destinations with local food identity. Therefore the research has purposes (1). Describe the visual communication design of food label of small and medium industry circulating in Bogor city. (2). Describe the aspects of small and medium industry food labels that have been adopted by small and medium-sized industries. (3). Analyze consumer buying interest in small and medium industries. The research method uses a qualitative approach where the analysis used is the case and the semantics of the product are visually observed. The results show that the local product has a cultural aesthetic value that is able to lift tourism by generating visual communication design, by showing the label information aspects of the production contained on the packaging. It can be able to attribute tourist visits in consuming local products by improving the quality of packaging product design.
\end{abstract}

Keywords: Design, IKM, Local Food

\section{PENDAHULUAN}

Bogor merupakan salah satu kota destinasi pariwisata yang kerap kali menjadi kunjungan masyarakat JABODETABEK serta di luar kawasan Jawa Barat. Hal ini berpotensi meningkatkan kesejahteraan masyarakat dengan mengembangkan industri pangan lokal yang berbasis produk yang unik, menarik, higienis lagi halal. Lebih dari lima puluh usaha kecil menengah binaan Kota Bogor telah mengembangkan produk desain lokal pangan sebagai bagian dari bingkisan buah tangan sebagai bentuk representasi dari Bogor sebagai kota hujan.

Industri Kecil dan Menengah salah satu sektor usaha kreatif yang di gagas setiap pemerintah daerah dan pusat sebagai sektor pembangunan industri yang menduduki posisi penting dalam perekonomian nasional. Sumbangan dari sektor ini terus meningkat dengan meningkatnya jumlah kunjungan wisatawan lokal maupun internasional. Hal ini berdampak pada penyerapan lapangan kerja kerja sebesar 8,75 juta orang dengan nilai produksi sebesar Rp. 521 triliyun dan sumbangan pendapatan devisa sebesar US\$ 13.5 Miliyar (Kementerian Perindustrian Republik Indonesia, 2012:10).

Oleh karena untuk meningkatkan daya saing dari sebuah produk diperlukan sebuah informasi yang akurat dari sebuah produk kemasan dalam sebuah pangan lokal. Zahara \&Triyanti (2009:7) menunjukkan dari hasil 
risetnya bahwa rerata pembeli sadar akan kualitas pangan yang baik yang tertera dalam kemasan pangan. Sehingga label pangan perlu memiliki informasi yang akurat sebagai bagian informasi awal dari pembeli. Tidak hanya dari harha namun juga kemasan yang menarik serta nilai gizi yang terkandung di dalamnya. Adapun Informasi keberadaannya penting bagi konsumen pada suatu label pangan antaralain label informasi komposisi dan nilai zat gizi yang merupakan keterangan tentang jenis bahan yang digunakan dan ditambahkan dalam proses produksi pangan.

Fajar (2008: 83) mengartikan label pangan merupakan bagian dari informasi barang berupa keterangan-keterangan tentang produk. Label adalah bagian dari produk yang membawa informasi verbal tentang produk atau tentang penjualnya. Label dapat berupa kemasan maupun lembar lepas yang ditempelkan pada produk. Adapun fungsi label, yaitu: (1) Label mengidentifikasikan produk atau merek, (2) Label berfungsi menggolongkan produk, (3) Menjelaskan beberapa hal mengenai produk, yaitu siapa yang membuat, dimana dibuat, kapan dibuat, apa isinya, bagaimana harus digunakan, bagaimana cara menggunakan dengan aman, (4) Sebagai alat promosi. Adapun jenis label bertujuan untuk (1) Brand identifisies, atau label brand merek, (2) Grade label, label yang menunjukkan tingkat kualitas tertentu suatu barang,(3) Descripting label, menggambarkan tentang cara penggunaan, pemeliharaan, dan features lainnya dari produk.

$$
\text { Penelitian Anam }
$$

memperlihatkan bahwa konsep dari label pangan berasal dari aturan yang berlaku dan kreasi dari produk lokal yang dikembangkan oleh pengusaha dalam melihat peluang bisnis. Produk ini senantiasa mendekatkan pada unsur budaya lokal sehingga mampu merepresentasikan bagian dari ke khasan wilayah setempat. Oleh karena itu kekhsan wilayah menjadi nilai jual produk sehingga mampu meningkatkan pendapatan produsen pangan. Hal ini diperkuat oleh Noviadji (2014:19) bahwa desain label pangan perlu menjadi bagian nilai jual tersendiri tidak hanya dilihat dari isi pangannya namun juga kemasannya yang menonjolkan informasi yang akurat dan menarik. Keberhasilan pemasaran produk makanan lokal ditentukan oleh mutu dan keamanan makanan, serta promosi yang dibarengi dengan upaya perbaikan tampilan kemasan yang fleksibel dan berlainan (unik) agar memiliki daya tarik tersendiri. Keberhasilan daya tarik kemasan ditentukan oleh estetika yang menjadi bahan pertimbangan sejak awal perencanaan kemasan karena dasarnya nilai estetika terkandung keserasian antara bentuk dan penataan desain tanpa melupakan kesan jenis, ciri, dan sifat barang/produk yang diproduksi. Sehingga untuk pangan khas tentunya kemasan tersebut mampu mencirikan suatu 


\section{Vol. 2 No.1 Agustus 2017}

daerah tertentu. Pada kasus penelitian tersebut peneliti melihat pada kasus produk lokal pangan yang bernama moci dengan merek dagang Mochibo dan Yum Mochi. Kedua produk ini diambil sebagai kasus karena distribusi kedua produk menjangkau ke luar daerah (tidak hanya Bogor) dan memiliki ketersediaan produk setiap hari. Oleh karena itu penulisan artikel ini bertujuan untuk : (1). Mendeskripsikan desain komunikasi visual label pangan industri kecil menengah yang beredar di Kota Bogor . (2). Mendeskripsikan aspek-aspek label pangan industri kecil menengah yang telah di adopsi oleh industri kecil menengah. (3). Menganalisis minat beli konsumen pangan industri kecil menengah.

\section{METODOLOGI PENELITIAN}

Metode penelitian menggunakan pendekatan kualitatif , dimana peneliti menggunakan realitas desain produk pangan dengan mencocokkan dengan praktek dan realitas yang terjadi dalam desain produk lokal pangan. Penelitian ini menggunakan teknik wawancara baik dengan pemilik, pembeli serta ahli desain produk kemasan. Produk pangan lokal yang diamati adalah produk yang sama jenis pangannya dan memiliki nilai jual yang dikenal oleh mayarakat. Produk yang diteliti adalah Mochibo dan Yum Mochi, dua kemasan ini merupakan kemasan dari kue mochi yang dikenal di Bogor dan di luaskan melalui produk pangan lokal Bogor. Selain itu peneliti menggunakan teknik obeservasi penjualan dimana tempat menjual produk tersebut.

Analisa penelitian ini menggunakan pendekatan kasus dimana keunikan dari kasus yang ada diamati dan difokuskan sebagai bagian bahan kajian untuk menjawab tujuan penelitian. Adapun alat yang digunakan adalah semantika dalam mengamati produk dan label pangan yang digunakan. Pendekatan ini juga digunakan oleh Anam (2015:566) dalam melihat kajian produk lokal yang menjadi ikonik dari sebuah kota atau daerah. Studi semantik merupakan maknamakna dalam bahasa yang menjelaskan unsur pemahaman kepada aspek kehidupan sehari hari yang berkaitan dengan kata lisan dan tulisan. Semantika produk lebih menitik bertakan pada makna-makna melalui cara berupa bahasa tulisan, alfabet, garis dan bentuk.

Semantika membentuk sebuah penanda yaitu tanda itu sendiri (fungsi desain), transmisi (objek), persepsi (rangsangan visual), dan tanggapan (makna). Produk membawa makna dan pemikiran yang berkaitan dengan tradisi, agama, situasi politik dan sosial, seni alam, iklim, dan seterusnya. Pelbagai aspek budaya didalamnya dapat diperspsikan dalam bentuk produk, warna, dan tekstur. Kajian ini muncul dari aspek bentuk (form), kandungan 


\section{Vol. 2 No.1 Agustus 2017}

isi (Symbol) dan ungkapan emosi (Expression). Sehingga menghasilkan model analisis formalisme, simbolisme, dan ekspresionisme. Penelitian ini dilakukan pada tahun 2017 pada produksi pada bulan Maret hingga Mei 2017.

\section{HASIL DAN PEMBAHASAN}

\section{Desain Komunikasi Visual Label Pangan IKM}

Desain label dalam produk kemasan merupakan hal yang mutlak dimiliki oleh produsen makanan lokal. Baik dalam bentuk paket kotak maupun dalam bentuk paket yang terbuat dari anyaman secara tradisional. Produk lokal yang menjadi objek kajian adalah Mochibo dan Yum Mochi yang merupakan produk mochi yang telah memiliki pangsa pasar. Dari kedua produk ini memiliki keunikan tersendiri meskipun mocha yang ditawarkan sama dengan isi kemasan sebanyak 12 buah dengan ragam variasi rasa yang sama seperti halnya talas, pala, nanas, keju, stroberi dan kacang serta cokelat. Dari kemasan yang dimiliki tergambar deskripsi kemasan di dua prodik tersebut adalah :

Tabel 1. Identitas Kemasan Produk Pangan Mochi Khas Bogor

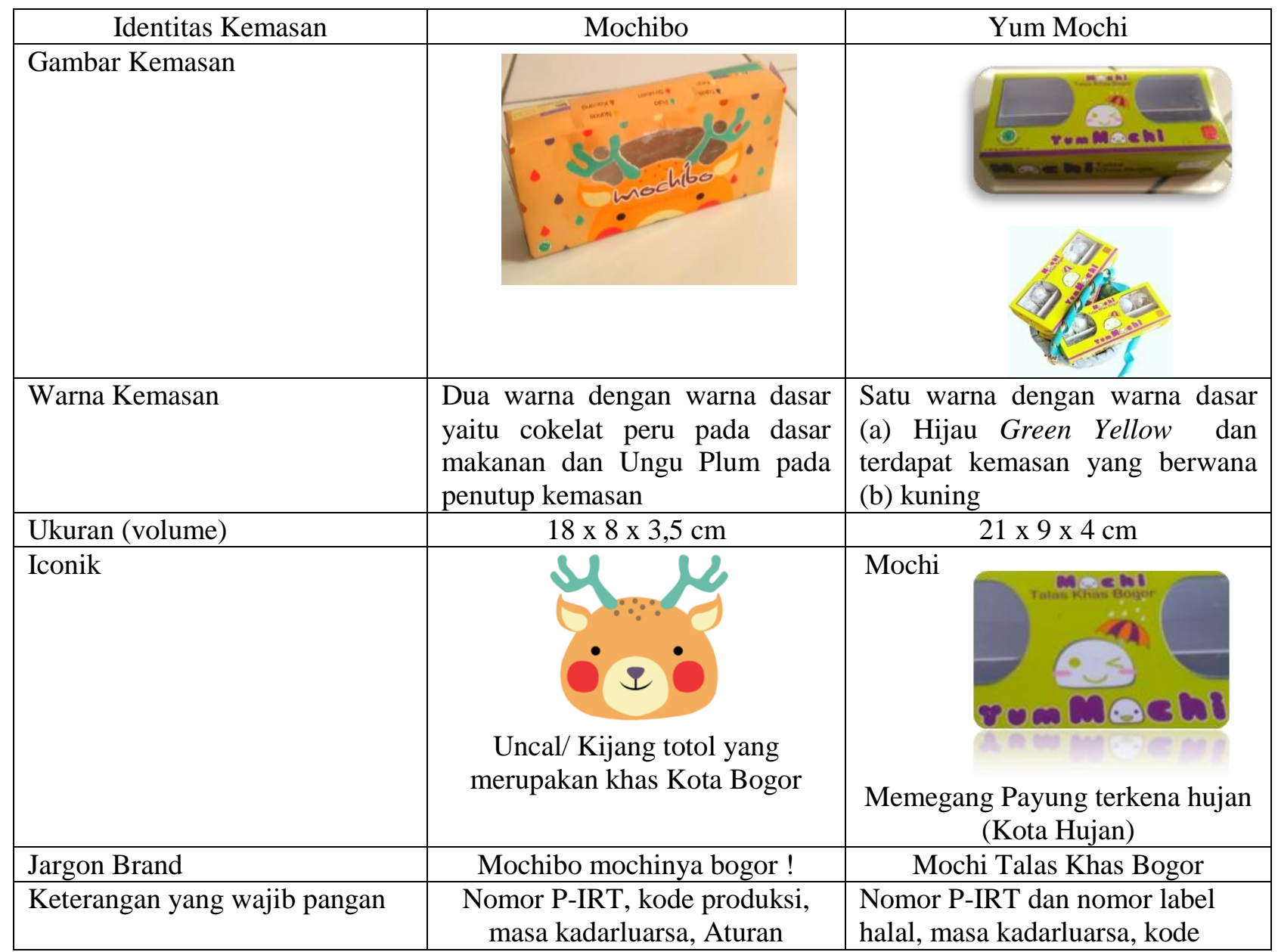


Vol. 2 No.1 Agustus 2017

\begin{tabular}{|l|c|c|}
\hline & Penyimpanan, Komposisi, Rasa & produksi, Komposisi, Rasa \\
\hline Keterangan tambahan pada label & $\begin{array}{c}\text { Alamat produksi dan nomor } \\
\text { kontak }\end{array}$ & $\begin{array}{l}\text { Alamat virtual melalui facebook, } \\
\text { twitter, Email }\end{array}$ \\
\hline Edukasi label & Memiliki Informasi Kota Bogor & Tidak memiliki \\
\hline
\end{tabular}

Mochibo sebuah produk kemasan pangan memiliki kemasan yang mungil dengan berat 360 gram. Produk ini memiliki kemasan kecil yang terdiri dari enam rasa. Pada kemasan tertulis jenis rasa yang dikehendaki oleh konsumen. Pada Mochibo memiliki ke khasan dimana memiliki informasi seputar Kota Bogor dimana menggambarkan semantika atau penanda Bogor itu sendiri. Adapun redaksi nya adalah "Tau ngak?" dengan tulisan yang berwarna merah diatas icon uncal dilanjutkan dengan "Selain kota hujan Bogor Juga disebut kota petir. Karena dalam sehari mendapat sembaran petir hingga 322 kali yang normalnya hanya 80 kali, ini tercatat dalam, Guinness book of world record", dengan semantika petir yang menunjukkan warna kuning pada tulisan tersebut. Disamping kolom tulisan lainnya tergambar uncal berada ditengah hutan yang diatas kepala uncal bertuliskan "Pada zama Belanda Kota Bogor disebut dengan nama "Buttenzorg" yang artinya kota tanpa kesibukan". Dan setelah gambar tersebut Uncal dengan mimik bertanya dengan katakata "Pensaran nggak kenapa ada banyak rusa di halaman Istana Bogor?" lalu dibawah redaksi tersebut dibalas dengan jawaban "Rusa-rusa tersebut didatangkan dari Nepal pada tahun 1808 . Tujuannya sebagai penghias halaman Istana Bogor yang dulunya merupakan tempat peritirahatan 38 Gubernur Jenderal Belanda".

Kemasan Mochibo memiliki kekhasan dimana mampu menghadirkan uncal/ kijang totol dan ikon Kota Bogor dari sisi realitasnya dimana Bogor sebagai kota istana rusa, dan asal rusa serta kota petir. Sosok Uncal yang digambarkan dengan identik dengan mochi yang bulat serta ditambah totol merah pada mukanya dan kepalanya yang diberi sepasang tanduk dan kuping serta hidung dan garis sebagai bibir Uncal. Mochibo merupakan akronim dari mochinya bogor yang ditulis di bawah gambar Uncal. Inilah yang menjadi semantika dalam produk Mochi. Dalam kemasan juga tergambar visit bogor dan $100 \%$ cinta Indonesia, label ini menunjukkan bahwa produk tersebut merupakan produk lokal yang berstandar nasional yang mendukung perkembangan ekonomi masyarakat Indonesia. Kemasan Mochibo juga menampilkan alamat produksi langsung dan nomor kontak yang dapat dihubungi sebagai bentuk tanggung jawab dari produsen kepada konsumen.

Berbeda halnya Yum Mochi dimana memiliki kuantiatas gambar yang standar dan tidak ramai dengan pernak-pernik serta menggambarkan aneka rasa yang di simbolisasikan dengan semantika mochi yang 


\section{Vol. 2 No.1 Agustus 2017}

beraneka mimik rasa. Mochi pada Yum Mochi memiliki iconik mocha yang membawa payung dimana lagi turun hujan. Hal ini semantika dari bahwa Kota Bogor adalah kota hujan dengan bertuliskan diatas Yum Mochi "Mochi Talas Khas Bogor" dengan tulisan berwana Ungu yang berdasar hijau yang memiliki semantika bahwa Kota Bogor memiliki pohon yang rindang dan hijau. Setiap tulisan pada Mochi dimana pada huruf "O" tergambar bentuk mochi itu sendiri. Yum Mochi menampilkan alamat virtual dimana pemesanan dapat dilakukan dengang facebook, twitter dan yahoo massengger.

Produk ini memperlihatkan bahwa kegiatan produksi hanya dapat diketahui oleh produsen sehingga bagi konsumen yang ingin mengetahui terlebih dahulu harus mengontak alamat virtual. Hal ini berdampak pada kemasan akan sulit terkonfirmasi oleh konsumen dan menimbulkan kecurigaan. Oleh karena itu alamat produksi penting untuk dicantumkan. Prasanti (2016:78) mensitir bahwa teknologi saat ini telah menjadi bagian kehidupan masyarakat, oleh karena itu, media sosial berupa komunikasi virtual telah menghiasi aspek ekonomi terutama pada pemasaran produk pangan. Walaupun demikian aspek realitas dalam pangan tetap harus dicantumkan. Alasan ini mendasar guna menjaga kehati-hatian dalam pangan lokal dan pangan olahan.
Kedua kemasan ini memiliki semantika yang berbeda dalam menampilkan kemasan dimana produk Mochibo menampilkan Uncal dan Yum Mochi menampilkan semantika kota hujan. Dari gambar ini menunjukkan bahwa identifikasi Bogor sebagai Kota Hujan dan rumah bagi kijang merupakan melekat pada Kota Bogor sendiri. Desain semantika yang dibangun menggunakan pendekatan topografi wilayah dan hewan khas Bogor itu sendiri. Anam (2015:569) mengugkapkan bahwa konsep desain dapat berupa potensi yang bisa dikembangkan di wilayah tersebut atau yang melekat dalam budaya dan unsur daya tarik sehingga mampu mengambil perbedaan dan ceruk pasar sebagai pembeda dengan produk yang lainnya. Oleh karena itu Mochi sendiri telah memperoleh nama representasi dari mochibo dan ataupun Yum Mochi dalam branding mochi Bogor sebagai bagian dari pasar oleh-oleh Bogor.

Meilani (2014:906) desain kemasan yang memiliki karakteristik yang baik memiliki perhatian lebih dari konsumen sehingga mampu memikat pasar. Hal ini sama halnya dengan produk-produk kemasan yang berasal dari Jepang berupa Banana Tokyo dimana produk tersebut mampu memikat pasar dan menjadi representasi dari negara sakura. Oleh karena itu perlu dorongan yang besar dilakukan oleh produsen dalam membangun branding untuk dapat diterima pasar. Cahyorini \& Rusfian (2011:18) menemukan bahwa desain 


\section{Vol. 2 No.1 Agustus 2017}

pada kemasan produk dapat mempengaruhi daya minat pembeli $38 \%$. Desain yang mampu mempengaruhi pembeli dapat berbentuk dari bentuk yang menarik, ringan serta mudah dibawa-bawa, warna yang menarik kontras baik tipologi maupun bentuk dasar pewarnaannya, selain itu gambar yang menarik perhatian pembeli (Nilsson \& Ostrom 2005: 102; Ampuero and Vila 2006; dan Klimchuk and Krasovec 2007: 49). Dari dua produk kemasan penelitian ini telah mampu memberikan nuansa desain yang menarik bagi makanan lokal sehingga mampu meningkatkan daya saing dan sanding dari produk.

\section{Aspek-Aspek Label Pangan IKM}

Terdapat beberpa label pangan yang wajib dimiliki bagi produk lokal yang akan menjualkan produk ke pasaran antara lain adalah : (1) Nama produk sesuai jenis pangan IRT yang terdaftar, (2) Bahan atau komposisi yang digunakan, (3) Berat bersih atau isi bersih, (4) Nama dan alamat IRTP, (5) Tanggal, bulan dan tahun kedaluwarsa, (6) Kode produksi, (7) Nomor P-IRT. Selain itu diperlukannya label halal (logo dan nomor registrasi halal). Aspek dari ketujuh hal yang wajib bagi pembeli untuk diamati dan dilihat sebagai bahan pertimbangan dalam membeli produk pangan.

Ketujuh aspek yang terdapat dalam label pangan ini telah dimiliki oleh kedua produk. Namun dalam produk Mochibo belum memiliki registrasi halal. Saat dikofinfirmasi ke pemilik Mochibo, label halal masih dalam tahapan pengurusan. Sedangkan Yum Mochi telah memiliki nomor registrasi izin layak jual dan halal. Menjadi unik dalam kedua kemasan penelitian ini adalah alamat IRTP, Mochibo menampilkan alamat produksi berupa lokasi langsung, Berbeda dengan Yum Mochi menampilkan alamat viral berupa twitter, facebook maupun yahoo messenger yang merupakan arena pemasaran yang digunakan. Kedua produk memiliki kemasan yang berbeda dari segi ukuran dengan beratyang sama. Yum Mochi lebih besar dibandingkan Mochibo. Sedangkan aspek kode produksi umumnya digunakan dari tanggal bulan dan tahun pembuatan, di beberapa usaha pabrikasi kode produksi disesuaikan dengan jenis produksi dalam bentuk barcoding.

Adapun aspek lain yang mampu menjelaskan perbedaan produk ini adalah dari segi komposisi yang dirahasiakan ratio penggunaannya. Pada Yum Mochi terterta komposisi "tepung ketan, kacang tanah, gula pasir, tepung tapioka, tepung talas, pasta talas dan keju”. Pada Mochibo tertera “tepung ketan putih, tepung tapioka, gula pasir, tepung gula, pewarna dan perasa, nanas Bogor, Pala Bogor, Talas Bogor, kacang tanah dan strawberry. Penampakan dari komposisi bahan yang digunakan secara dasar sama namun bahan pengaya berbeda satu produk dengan produk lainnya. Aspek pangan dari kedua produk ini telah mengikuti standar dari keamanan pangan 


\section{Vol. 2 No.1 Agustus 2017}

dengan informasi label yang digunakan. Nilsson \& Ostrom (2005:102) mengemukakan bahwa informasi dari suatu produk label pangan haruslah membuat nama produk, warna, typografi serta gambar produk. Produk tersebut dapat mewakii secara bentuk, ukuran dan isi. Klimchuk \& Krasovec (2007:49) menekankan bahwa gambar, ilustrasi serta symbol atau iconic dan karakter dari produk dapat mewakili dari label produk hingga mampu diterima atau komunikatif di hadapan konsumen yang akan membeli.

Aspek pangan bagi industri rumah tangga (IRT) wajib bagi konsumen untuk diketahui sebagai informasi awal dalam membeli sehingga mampu meningkatkan daya sensivitas pembeli sebagai raja. Hal ini juga sebagai kewajiban bagi produsen untuk menampilkan produk tanpa mengenyampingkan aspek lain dengan estetika yang baik. Meilani (2014:904) melihat bahwa banyak produk lokal Indonesia masih banyak belum mampu melakukan label informasi produksi seakurat dan mengedepankan nilai estetika. Hal ini wajar saja terjadi demikian disebabkan oleh keterbatasan modal dan kreasi dari desainer yang kurang memahami produk dari segi desain dan sumber produk. Hal ini membutuhkan survey lapang yang tidak sebentar dan membutuhkan temuan dan inovasi tersendiri hingga membentuk brand label yang dikenal masyarakat.
Berbeda dengan dua produk yang diteliti telah mampu menawarkan dan mengenalkan brand label pangan yang efektif sehigga dapat diterima pasar yang terus mengalami perubahan. Oleh karena itu, aspek label pangan yang wajib perlu diperhatikan jangan sampai mengenyampingkan aspek estetika gambar yang tidak mewakili keamanan pangan itu sendiri. balik fungsinya. Sehingga kemasan oleh-oleh yang beredar di pasaran tidak hanya sekedar dikemas dengan desain sekedarnya, tetapi dilakukan dengan kesungguhan estetika untuk mendapatkan citra yang baik dan meningkatkan promosinya. Merupakan nilai tambah jika pada akhirnya ada suatu produk Indonesia yang diburu oleh para pelancong dan menjadikannya sebagai produk wajib yang harus dibeli jika berkunjung ke Indonesia.

\section{Minat Beli Konsumen Terhadap Pangan IKM}

Tingginya minat beli masyarakat merupakan salah satu majunya perekonomian masyarakat suatu negara. Minat beli dalam suatu produk dipengaruhi oleh faktor secara psikologis dari personal pembeli baik berupa perhatian yang disebabkan oleh atribut dari produk yang unik dan menarik disesuaikan dengan kebutuhan yang dimiliki oleh pembeli. Ketertarikan ini muncul lahir dari visualisasi yang lahir dari desain dan kebutuhan pembeli. Hal inilah apa yang disebut oleh Bone \& France (2001:475) bahwa visualisasi dari 


\section{Vol. 2 No.1 Agustus 2017}

produk berupa (gambar dan warna) mempengaruhi persepsi konsumen untuk membeli.

Lahirnya ketertarikan suatu produk membuahkan hasil keinginan untuk memiliki yang dapat dipengaruhi oleh, Silayoi \& Speece (2004:1510) menyebutnya sebagai dari elemen visual yang menimbulkan keyakinan untuk memutuskan membeli. Nayyars (2012:14) melihat bahwa mayoritas keputusan pembeli disebabkan oleh warna yang sesuai dengan kebutuhan yang dimiliki dimana pembeli telah mengatribusikan produk sesuai dengan jenis barang yang digunakan. Selain itu pemahaman konsumen terhadap informasi produk dan kenyamanan pembeli sangat dominan sebagai preferensi pembeli dalam memilih produk. Dadras (2015:48) menambahkan bahwa demografi suatu pembeli juga memengaruhi variasi prereverensi dari produk. Faktor demokrafi lahir dari identitas pembeli maupun produk.

Noviadji (2014:14) kemasan mampu memberikan harga jual yang tinggi selain memiliki fungsi promosi, media informasi, serta identitas dari makan sehat, bersih dan higienis. Minat beli tergantung atas kemauan sesuai dengan selera konsumen. Konsumen akan memilih kemasan yang rapi, bersih dan memiliki identitas produk yang jelas. Dari hasil wawancara dengan konsumen ketertarikan kepada dua produk Mochibo dan Yum Mochi memiliki tingkat minat yang sama.
Hal ini di tuturkan oleh pemilik Mochibo bahwa produk Mochibo menjaga keaslian rasa dan merek dagang, meskipun pada masa tidak libur Mochibo dipasarkan dengan kemasan jajanan anak sekolah dasar dengan bentuk yang terbuka namun kualitas rasa yang tetap dijaga. Berbeda dengan Yum Mochi yang hanya dipasarkan dengan kemasan kotak sehingga produksi yang dihasilkan hanya untuk produksi wisata.

Minat beli konsumen dalam produk pangan lokal sangat ditentukan oleh waktu yang berbanding lurus dengan masa libur panjang dan akhir pekan yang lebih dimanfaatkan oleh keluarga untuk berlibur dan berkumpul bersama dengan keluarga. Secara komunikasi psikologi pemasaran minat beli produk pangan sangat didominasi oleh informasi awal yang didapat dari media virtual dan kunjungan langsung ketika terdapat festival food di Kota Bogor. Saat ini minat beli Mochi pada momen liburan memiliki tingkat kenaikan yang berarti mampu melebihi target penjualan.

Berbeda dengan hari-hari biasa Mochi sulit untuk bertahan dengan produk pangan lokal lainnya karena minat pembeli terbagi dengan produk lainnya. Spesifikasi Mochi lebih pada pangan ringan yang dikonsumsi pada saat rekreasi maupun hidangan saat pencuci mulut. Oleh karena itu Mochi merupakan alternatif pilihan pangan dalam mengkonsumsi makanan sehat, tradisional dan 


\section{Vol. 2 No.1 Agustus 2017}

enak. Mochi, makanan tradisional yang naik derajat menjadi makanan yang mahal dan memiliki nilai estetik yang diterima semua kalangan terutama kalangan kelas atas. Hal ini tak terlepas dari desain visual produk yang mendukung semantika dari iconik Kota Bogor. Senada apa yang menjadi temuan dari Meilani (2014:905), bahwa produk yang memiliki nilai branding yang baik akan memilki pasar yang khas meskipun makanan tersebut bernilai tradisional. Nilai branding sangat dipengaruhi oleh desain visual yang terdiri dari bentuk, warna, informasi produk serta, isi dari produk tersebut.

Berdasarkan hasil obeservasi di lapangan minat beli konsumen sangat dipengaruhi oleh komitmen pengusaha industri makanan. Oleh karena itu berdampak pada peningkatan branding dari produk yang di jual. Penjualan sacara langsung dan on line memiliki pengaruh yang cukup tinggi untuk memperkenalkan produk meskipun tidak mersakan secara langsung sampelnya. Oleh karena itu terdapat hal yang berpengaruh terhadap minat beli pangan lokal adalah (1) kemasan yang menarik sehingga menjadi viral dalam media sosial, (2) harga yang mampu dijangkau oleh konsumen, (3) informasi produk yang baik lagi sehat dan halal, (4) alamat produksi yang jelas mampu di akses secara langsung.

Keempat inilah menjadi komitmen yang perlu dibangun oleh industri kecil menengah atau IKM untuk membangun kepercayaan masyarakat terhadap pangan lokal yang sehat dan higienis. Oleh karena itu diperlukan peningkatan kualitas desain produk. Tujuan akhir dari perbaikan kualitas desain yang menarik adalah peningkatan selera konsumen terhadap pangan lokal yang meningkatkan lapangan kerja serta pendapat masayarakat secara langsung. Sehingga instrumen menjadikan suatu kemasan baik atau tidak baik adalah standar pangan yang sehat yang di jelaskan pada Peraturan Pemerintah no 28 Tahun 2004 tentang kemasan produk. Terlebih pangan tersebut memiliki nilai halal yang telah di legalitaskan. Minat beli yang tinggi berbanding lurus dengan daya repitisi dari konsumen sehingga mampu meningkatkan IKM lokal untuk dapat meningkatkan kualitas desain yang menarik dan standar.

\section{PENUTUP}

\section{Simpulan}

1. Produk Mochibo dan Yum Mochi telah sesuai dengan kaedah desain komunikasi visual yang memiliki daya pikat konsumen dengan mempertimbangkan aspek bentuk, ukuran, warna, infomasi produk serta nilai budaya konsumen itu sendiri.

2. Aspek-aspek label pangan perlu menjadi konsentrasi bagi produsen dan tim pembuat kemasan dalam menampilkan produk yang menarik dan sederhana namun memiliki nilai estetika yang tinggi. 


\section{Vol. 2 No.1 Agustus 2017}

3. Aspek label pangan bagian dari konsentrasi konsumen dalam memilih produk sehingga dapat diterima konsumen untuk dikonsumsi oleh karena itu produk Mochibo dan Yum Mochi telah mengadopsi standar kemasan yang diatur dalam Peraturan Pemerintah No. 28 tahun 2004.

4. Minat beli masyarakat terhadap pangan lokal sangat tinggi dengan prinsip produk tersebut kekinian dan memiliki kemasana serta promosi yang menarik bagi masyarakat konsumen. Peningkatan minat ini dipengaruhi oleh waktu dan momentum yang sesuai dengan demografi dan selera masyarakat.

\section{Saran}

1. Perlunya kreasi desan visual produk dengan mengetahkan semantika demografi baik topografi, budaya, makan lokal dan lainnya yang biasa disebut iconik.

2. Perlunya evaluasi desain produk lokal telah sejauh mana mewakili ikon Kota Bogor sebagai Kota Pariwisata dengan parameter aturan baku pemerintah yang bersumber dari Undang-Undang tentang pangan No 7 Tahun 1996 serta Peraturan Pemerintah no 28 Tahun 2004 tentang kemasan produk serta uji desain dari para pakar dan masukan dari pemerhati produk.

3. Perlunya pengembangan desain-desain yang didasarkan pada nilai jual pariwisata yang dibangun oleh pemeritah dan korporasi sehingga mampu membentuk branding yang memiliki nilai jual yang loyal pada pembeli.

\section{DAFTAR PUSTAKA}

Ampuero O \& Villa N. (2006). Consumer Perceptions of Product Packaging. Journal of Consumer Marketing.

Anam C. (2015). Pengembangan Desain Sepatu Wanita Dengan Keunikan Lokal Kota Surabaya. Seminar Nasional Sains dan Teknologi Terapan III, Institut Teknologi Adhi Tama Surabaya : 563-572.

Bone PF \& France KR. (2001). Package graphics and consumer product beliefs. Journal of Business and Psychology, 15 (3): 467-489.

Cahyorini A \& Rusfian EZ. (2011). The Effect of Packaging Design on Impulsive Buying. Journal of Administrative Science \& Organization, 18(1) : 11- 21.

Dadras, A. (March 30, 2015). Impact of Consumers Demographic Factors on Rice Packaging Design in the Lens of Kanos Attractive Quality Theory. International Journal of Innovative and Applied Research, 3(3) : 43-53.

Fajar L. (2008). Manajemen Pemasaran Pedekatan Praktis. Graha Ilmu. Yogyakarta.

Kementerian Perindustrian Republik Indonesia. (2012). Buku Petunjuk Teknis Penilaian, Klasifikasi dan Pembinaan Produk Ovop. Direktorat Jenderal Industri Kecil dan Menengah Kementerian Perindustrian. 
Klimchuk MR \& Krasovec SA. (2007). Desain Kemasan: Perencanaan Merek Produk yang Berhasil Mulai dari Konsep sampai Penjualan (Bob Sabran, Penerjemah.). Jakarta : Erlangga.

Meilani. (2014). Pencitraan Desain Kemasan Oleh-Oleh Jepang. Humaniora, 5(2) : 901-908.

Nayyars E. (2012). Packaging - An Innovative source of Impulsive and Abrupt Buying Action. International Journal of Management \& Information Technology, 1(1): 13 - 16.

Nilsson J \& Ostrom T. (2005). Packaging as a Brand Communication Vehicle. Thesis of Lulea University of Technology.

Noviadji BR. (2014). Desain Kemasan Tradisional Dalam Konteks Kekinian. Jurnal Fakultas Desain 1(1) : 10-21.
Prasanti D. (2016). Perubahan Media Komunikasi Dalam Pola Komunikasi Keluarga Di Era Digital. Jurnal Commed Vol 1. No. 1 Agustus: 69-81

Silayoi P \& Speece M. (2007). The Importance of Packaging Attributes: a Conjoint Analysis Approach. European Journal of Marketing, 41(11/12): 1495 -1517 .

Susann V \& Seppo V. (2009). Semiotika Visual dan Semantika Produk. Yogyakarta: Jalasutra.

Zahara S \& Triyanti. (2009). Kepatuhan Membaca Label Informasi Zat Gizi di Kalangan Mahasiswa. Jurnal Kesehatan Masyarakat Nasional. 4(2). 